\title{
Pharmacological screening and acute toxicity of bark roots of Guettarda platypoda
}

\section{Evelyn M. L. Pina, ${ }^{1,2}$ Fernando W. C. Araújo, ${ }^{1}$ Ivone A. Souza, ${ }^{1}$ Isla V. G. A. Bastos, ${ }^{1}$ Teresinha G. Silva, ${ }^{1}$ Silene. C. Nascimento, ${ }^{1}$ Gardenia C. G. Militão, ${ }^{1}$ Luiz. A. L. Soares, ${ }^{2}$ Haroudo S. Xavier, ${ }^{2}$ Sebastião J. Melo ${ }^{*}, 1$}

${ }^{1}$ Departamento de Antibióticos, Universidade Federal de Pernambuco, Brazil, ${ }^{2}$ Departamento de Farmácia, Universidade Federal de Pernambuco, Brazil.
Revista Brasileira de Farmacognosia Brazilian Journal of Pharmacognosy 22(6): 1315-1322, Nov./Dec. 2012

\begin{abstract}
Due to its folk use, scientific reports and phytochemical screening, the purpose of this work was to study the phytochemical and the biological properties of the methanol extract and to evaluate the anti-inflammatory activity as well as determine the acute toxicity, antitumor and cytotoxic activity of the root barks of Guettarda platypoda DC., Rubiaceae. In this analysis the presence of flavonoids and therpenoids were identified. These data and the ones in the literature indicated it as a potential antioxidant and motivated the cytotoxic analysis related with three tumoral cell strains as well as to evaluate its antitumoral activity (sarcoma 180 and Ehrlich carcinoma) in female mice. Due to the presence of esteroids and the previous study of the ethanolic extract, its anti-inflammatory activity and toxicity were also evaluated. Absence or low toxicity in $2000 \mathrm{mg} / \mathrm{kg}$ doses was verified and the attention to their phytochemical and pharmacological properties is constantly increasing.
\end{abstract}

Received 19 Mar 2012

Accepted 6 Jul 2012

Available online 9 Oct 2012

Keywords: acute toxicity anti-inflammatory activity antitumor activity cytotoxicity Guettarda platypoda

ISSN 0102-695X http://dx.doi.org/10.1590/S0102695X2012005000118

\section{Introduction}

The chemical and pharmacological potential of higher plants due to the identification of their secondary metabolites has long been known and the attention to their phytochemical and pharmacological properties is constantly increasing. Stems, flowers, leaves, roots, tubercle, seeds and fruits are targets of interdisciplinary studies in order to broaden the knowledge of their properties.

It is reported that from nearly 400000 plant species existing on our planet (IGEduca, 2010), Brazil has about 55000 of these in its territory. Thus, Brazil has one of the highest biodiversity in the world, featuring a variety of biomes that reflects the richness of flora and fauna. For this reason, it is one of the most important regions among the so-called mega-diverse and, many species found in Brazilian biomass are unique (endemic) (Portal Brasil, 2011). Due to this, it is easy to deduce the potential of bioactive products from the plants, and a large number of plant species in Brazil has still not been studied from the chemical and/ or pharmacological point of view (Cunha et al., 2003; David et al., 2006).

Among the angiosperms, the most representative is the Rubiaceae family, being the fourth largest in Dicotyledons, comprising about 13000 species in 650 genera and 44 tribes (Delprete, 2004). Its species are found in tropical and subtropical regions, and can also reach the temperate and cold regions of Europe and northern Canada (Pessoa, 2009). In the Americas, the family Rubiaceae is represented by 217 genera and 5000 species and in Brazil, about 120 genera and 2000 species, representing one of the leading families of our flora. This family is present in almost all natural formations: forest, Cerrado, Caatinga, shoal, rainforest, forest and mountain altitude, trays, dunes and open fields (Delprete, 2004; Lima et al., 2010; Pereira, 2002). According to Barbosa et al. (2011), the Rubiaceae family also stands out among the most diverse in the Brazilian Northeast, with 66 genera and some 310 species.

One of the representatives of this family is the genus Guettarda, composed of about 180 species known widely distributed in the tropical and neotropical zone, with the occurrence of 24 species distributed throughout the Brazilian territory (Mól, 2010). They are used in folk medicine for various purposes, mainly in the treatment of wounds and inflammation (Agra et al., 2007, 2008; Bertucci et al., 2008; Capasso et al., 1998).

Guettarda platypoda DC., Rubiaceae is found in the coastal plain of northeast of Brazil and is known as "angelica" or "angelica-do-mato" (Andersson, 1992; Pereira \& Barbosa, 2004). G. platypoda is a shrub and its root is used in folk medicine as a febrifuge (Aquino et al., 1988a,b; Bhattacharyya \& Almeida, 1985; Ferrari 
et al., 1986), as well as during the puerperal period (Bhattacharyya \& Almeida, 1985; Matos, 1997) and to correct menstrual irregularities (Bahia, 1979).

The objective of this work was to perform the phytochemical analysis and to evaluate the antiinflammatory activity as well as to determine the acute toxicity, antitumor and cytotoxic activity. As the population of the northeast of Brazil uses this plant for medicinal purposes, and very few data were available, it was decided to evaluate its pharmacological potential, toxicity and safety levels of employment.

\section{Materials and Methods}

\section{Plant material}

The barks of Guettarda platypoda DC., Rubiaceae, were collected in August 2009 in the Island Itamaracá (Pernambuco, Brazil). The plant was identified by Rita de Cássia Araújo Pereira and a voucher specimen was deposited at Dárdano de Andrade Lima Herbarium, Agronomic Institute of Pernambuco (IPA), under the number 86565 .

\section{Preparation of methanolic extract}

After G. platypoda roots were collected the barks were immediately removed from them and left to dry at room temperature $\left(25 \pm 2{ }^{\circ} \mathrm{C}\right)$ for seven days. They were weighed and triturated in an electric mill to obtain a fine granulated powder. The preparation of the methanolic extract was obtained by an infusion of $700 \mathrm{~g}$ of bark roots in $2000 \mathrm{~mL}$ of methanol, followed by $72 \mathrm{~h}$ maceration with sporadic agitation. The extract was filtered and the plant residue was re-extracted two more times. The filtered was concentrated in a rotary evaporator at $50^{\circ} \mathrm{C}$, to obtain the Crude Dry Extract (CDE).

\section{Phytochemical analysis}

Using silica gel plates (Alugram ${ }^{\circledR}$ SIL G/UV254, Ref: 818133$), 10 \mu \mathrm{L}$ aliquots were subjected to thin layer chromatography (TLC) to analyze the presence of the main secondary metabolites: flavonoids, cinnamic derivatives, phenylpropanoid glycoside (Neu, 1956; Wagner \& Bladt, 1996), condensed proanthocyanidins, leuco-anthocyanins (Roberts et al., 1957), monoterpenes, sesquiterpenes, diterpenes (Wagner \& Bladt, 1996), triterpenes, steroids (Harbone, 1998; Sharma \& Dawra, 1991), cardiac glycosides, alkaloids (Wagner \& Bladt, 1996) and reducing sugars (Russel, 1982), employing the respective standards and specific revelators. The saponin presence was tested by afrogenicity, according to the methodology by Costa (2001).

\section{Animals}

Adult female mice (Mus musculus) weighing 25-35 g were obtained from the Antibiotics Department of the Federal University of Pernambuco. The animals were kept in polypropilene cages with water and ration (Labina Purina Brazil) ad libitum, under controlled lightness, light and dark cycles of $12 \mathrm{~h}$ and of temperature $\left(23 \pm 2{ }^{\circ} \mathrm{C}\right)$.

The experimental procedure was performed according to the ethical principles of CEEA (Ethics Committee of Animal Experiments) of Federal University of Pernambuco under the number 23076.013788/2009-82.

\section{Acute toxicity evaluation}

The mice were submitted to acute toxicity essay according the OECD 423 protocol (2001). The $\mathrm{CDE}$ was given orally. After $8 \mathrm{~h}$ of fasting, the animals received a $2000 \mathrm{mg} / \mathrm{kg}$ and $3000 \mathrm{mg} / \mathrm{kg}$ doses and were observed during the first $24 \mathrm{~h}$ and daily for fourteen days period. At the end of fourteen days, they were sacrificed in $\mathrm{CO}_{2}$ chamber and taken to autopsy for macroscopic observation of the organs (liver, kidney and spleen).

\section{Anti-inflammatory activity evaluation}

The carrageenan-induced peritonitis experiment was conducted in female mice $(n=6)$ as describe by Uchôa et al. (2009). One hour before the experiment, the animals received the G. platypoda CDE orally in doses of 30,50, 100,150 and $200 \mathrm{mg} / \mathrm{kg}$. The standard group received the vehicle ( $10 \%$ propylene glycol in saline, orally). Mice were injected intraperitoneally with $0.25 \mathrm{~mL}$ of carrageenan $(1 \%$ in saline solution). After $4 \mathrm{~h}$, the animals were sacrificed in $\mathrm{CO}_{2}$ chamber and immediately submitted to surgery to have their chest opened, which was flushed with $3 \%$ of saline solution containing $3 \mu \mathrm{M}$ of EDTA. The collected exudates were centrifuged and re-suspended in saline solution and the count of polymorph nuclear leucocytes (PMNL) was performed in cell automatic counter (Micros 60) (Vital et al., 2009).

\section{Antitumor evaluation (Sarcoma 180 and Ehrlich} carcinoma)

The antitumor experiment was performed according to Sugiura et al. (1955) method. After removing the tumor mass from the donor animal, it was placed in physiologic solution associate with an antibiotic, separating necroses from the other parts. After this, the fragments (about $3 \mathrm{~mm}$ ) were induced by subcutaneous way in the receptor animals. The 
animals were then divided in three groups (six animals per group). During the experiment (seven days), the animals were weighed and the control group received $0.5 \mathrm{~mL}$ of physiological solution orally, the positive group was treated with methotrexate $(2.5 \mathrm{mg} / \mathrm{kg}$ oral way) and to the test group G. platypoda CDE in doses of 100 and $200 \mathrm{mg} / \mathrm{kg}$ was administered. The experimental chemotherapy was started $48 \mathrm{~h}$ after the transplant. At the end of the treatment ( $8^{\text {th }}$ day) all the animals were weighed and sacrificed, and the organs (liver, kidneys, heart, lung and spleen) were removed and weighed, as well as the tumors were also excised, dissected and weighed. The tumor inhibition was calculated as: Inhibition ratio (\%) was calculated as: inhibition ratio $(\%)=[(\mathrm{A}-\mathrm{B}) \mathrm{A}] \times 100$, where $\mathrm{A}$ is the average tumor weitht of the negative control, and $\mathrm{B}$ is that of the treated group.

\section{Cytotoxicity evaluation}

The cytotoxic potential of Crude Dry Extract was evaluated by the MTT assay (Mossman, 1983), comparated with three human tumor cell lines: HT29 (human colon carcinoma), MCF-7 (breast human carcinoma) and NCI H-292 (lung human cancer) obtained from Rio de Janeiro's Cell Bank Brazil. All cell lines were maintained in DMEN medium supplemented with $10 \%$ fetal bovine serum, $100 \mathrm{U} / \mathrm{mL}$ penicillin and $100 \mathrm{mg} / \mathrm{mL}$ streptomycin, at $37{ }^{\circ} \mathrm{C}$ with $5 \% \mathrm{CO}_{2}$. The cells were plated in 96-well plates at $1 \times 10^{5}$ cells $/ \mathrm{mL}$. The G. platypoda CDE was diluted in DMSO $0.1 \%$ and tested in quadruplicate in $50 \mu \mathrm{g} / \mathrm{mL}$ concentration. After $72 \mathrm{~h}$ of incubation, $25 \mu \mathrm{L}$ of MTT $(5 \mathrm{mg} / \mathrm{mL})$ was added. Three hours later the MTT formazan product was dissolved in $100 \mathrm{~mL}$ DMSO and absorbance was measured at $595 \mathrm{~nm}$. The experiments were carried out in duplicate and they were analyzed according to their averages and standard deviations employing the Graph Pad Prism program.

\section{Statistical analysis}

All results were expressed as mean values \pm SD for each experimental group. Statistical analysis between groups was performed by one-way analysis of variance (ANOVA), followed by Tukey's test. For a confidence interval of $95 \%$, only $p$ values less than 0.05 $(p<0.05)$, as determined by BioEstat (version 5.0), were considered to be indicative of statistical significance.

\section{Results}

Phytochemical analysis

The phytochemical analysis enables the identification of the secondary metabolites, which may be related to biological activities. The phytochemical profile from the methanol extract of the root bark of Guettarda platypoda DC., Rubiaceae, detected the presence of flavonoids, cinnamic derivatives, phenylpropanoid glycoside, monoterpenes, sesquiterpenes, diterpenes, triterpenes, steroids, saponins and reducing sugars. The other metabolites (condensed proanthocyanidins, leuco-anthocyanins, cardiac glycosides and alkaloids) were not detected in the tests. A strong violet coloration was observed in the chromatographic test for triterpenes/steroids identification, which may indicate the presence of triterpene acids (oleanolic acid or ursolic acid). The presence of steroid beta-sitosterol was found in the extract, afrogenicity was found in the test, and the presence of saponins was indicated by the existence of an intense foam which lasted for more than $24 \mathrm{~h}$.

\section{Acute toxicity evaluation}

Some signs and unusual symptoms during the first $60 \mathrm{~min}$ of the acute toxicity protocol were observed (Table 1): as exciting behavioral (agitation, touch response, tachycardia and tremor), inhibitory (sleepiness) and others characteristics (piloerection and tail quivering).

However, in this study, no death was observed fourteen days after acute treatment with high doses (2000 and $3000 \mathrm{mg} / \mathrm{kg}$ ) of G. platypoda CDE, so it was not possible to calculate the LD50, considered here as greater than $3000 \mathrm{mg} / \mathrm{kg}$. The treated animals did not show any significant alteration in water or food consumption, or in body weight (Table 2) during the experimental period. In addition, macroscopic examination revealed that the organs taken presented aspect of color, size and texture, showing no difference from the control group, with the remaining aspects preserved.

\section{Anti-inflammatory activity evaluation}

The results obtained in the carrageenaninduced peritonitis test are shown in Table 3 . The data revealed that the doses tested with the Groups 2, 3, 4 and $5(50,100,150$ and $200 \mathrm{mg} / \mathrm{kg}$, respectively) caused a significant reduction in the migration of polymorphonuclear leukocytes in comparison to the control group, presenting a promising anti-inflammatory activity. But, between these groups no statistically significant difference was observed.

\section{Antitumor activity evaluation}

The effects of $G$. platypoda $\mathrm{CDE}$ in mice 
transplanted with the tumor sarcoma 180 and Ehrlich carcinoma are shown in Figure 1 and 2, respectively. Compared with the mean tumor weight control group treated with saline solution, the groups treated with 100 $\mathrm{mg} / \mathrm{kg}(74,26 \%)$ and $200 \mathrm{mg} \mathrm{kg}(84,77 \%)$ doses, had the men weight of sarcoma 180 tumors reduced (Figure 1). The positive control group, metotrexato $(2.5 \mathrm{mg} /$ $\mathrm{kg}$, oral way) had $89 \%$ tumor inhibition. In the animals transplanted with Ehrlich carcinoma, of the treatment with G. platypoda CDE presented a slight increase of the average weight of the tumor, however this decrease was not statistically significant. The positive control group (metrotexate) showed $92 \%$ inhibition in the growth of Ehrlich carcinoma.

Table 1. Clinical signs of acute toxicity observed in adult female mice (Mus musculus), treated with different doses CDE of Guettarda platypoda by oral doses.

\begin{tabular}{lccc}
\hline \multirow{4}{*}{ Parameters } & \multicolumn{3}{c}{ Groups } \\
\cline { 2 - 4 } & $2,000 \mathrm{mg} / \mathrm{kg}$ & $3,000 \mathrm{mg} / \mathrm{kg}$ & Group control \\
\hline Agitation & \multicolumn{2}{c}{ Stimulants } & ++ \\
Convulsions & +++ & +++ & ++ \\
Vocal fremitus & - & - & - \\
Irritatacion & + & - & - \\
Stereotyped & - & - & - \\
movements & - & ++ & - \\
Touch Response & + & ++ & - \\
Salivation & - & - & - \\
Tachycardia & ++ & +++ & - \\
Tremors & ++ & ++ & - \\
\hline \multicolumn{5}{c}{ Inhibitory } & & \\
\hline Abdominal writhing & - & + & - \\
Stretch & - & - & - \\
Ptosis & - & - & - \\
Sleepiness & ++ & +++ & + \\
Hindquarter & - & + & - \\
\hline \multicolumn{5}{c}{ Cyanosis } & \multicolumn{1}{c}{ Other } & & - \\
Defecation & + & - & - \\
Diarrhea & - & ++ & + \\
Tearing & - & - & - \\
Urination & + & + & - \\
Piloerection & + & + & - \\
No of deaths & 0 & 0 & 0 \\
\hline- no effect; +: light effect; ++: moderate & effect; +++: major effect.
\end{tabular}

During the experiments it was observed that all the animals presented no significant weight changes Mice with Sarcoma 180: $90 \%$ of the ST1 or ST2 experimental groups presented hyperemic, friable, fibrous-looking lungs, one of the ST1 group presented kidneys with a cystic appearance Mice with Ehrlich carcinoma; it was macroscopically verified that two animals of CT1 group presented lung hemorrhage. With these exceptions, the mice of both strains, and independent of treatment, showed no macroscopic changes in their organs, with no fibrous consistency, thrombus, lesions and atrophy on the edge of the organs, preserving aspects in relation to structure, texture and shape. The tumors were well-defined and had a solid consistency (Figure 3).

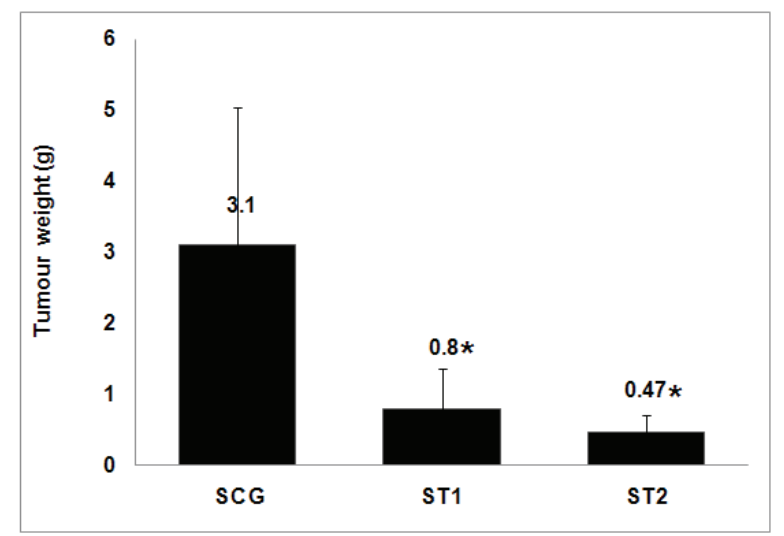

Figure 1. Antitumor activity of Guettarda platypoda CDE in Mus musculus female mice after implantation of Sarcoma 180. Saline $(0.5 \mathrm{~mL})$ was orally administered in the Control Group (SCG) and experimental treated groups (ST1=100 mg/ $\mathrm{kg} ; \mathrm{ST} 2=200 \mathrm{mg} / \mathrm{kg}$ ) for seven days. ${ }^{*} p<0.05$.

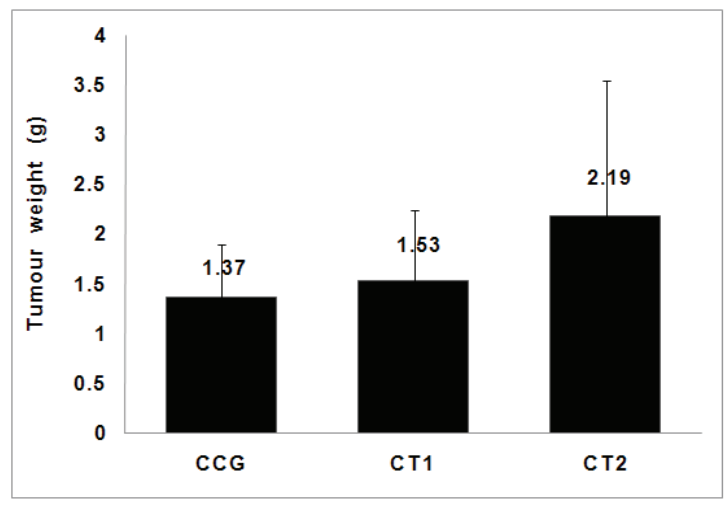

Figure 2. Antitumor activity of Guettarda platypoda CDE in Mus musculus mice after implantation of Ehrlich carcinoma. Saline $(0.5 \mathrm{~mL})$ was orally administered in the Control Group (SCG) and experimental treated groups (CT1=100 mg/kg; $\mathrm{CT} 2=200 \mathrm{mg} / \mathrm{kg}$ ) for seven days. ${ }^{*} p<0.05$.

\section{Cytotoxicity evaluation}

According to the results, CDE did not present cytotoxicity for any of the strains tested. The intensity scale used to evaluate the cytotoxic potential of the samples tested was: samples with no activity (10-20\% inhibition), with few activity (cell growth inhibition ranging from 20 
Table 2. Weight gain and physiological habits (consumption of water/diet) in adult female mice (Mus musculus), treated with different doses of G. platypoda CDE in acute toxicity by oral doses.

\begin{tabular}{lcccc}
\hline \multirow{2}{*}{ Groups } & \multicolumn{2}{c}{ Body weight } & Consumption of water $(\mathrm{mL})$ & Consumption of diet $(\mathrm{g})$ \\
\cline { 2 - 4 } & Initial $(\mathrm{g})$ & Final $(\mathrm{g})$ & $31.07 \pm 6.59$ & $11.28 \pm 4.69$ \\
\hline Control & $22.6 \pm 0.85$ & $27.7 \pm 1.11$ & $30.71 \pm 9.83$ & $12.77 \pm 2.21$ \\
$2000 \mathrm{mg} / \mathrm{kg}$ & $24.6 \pm 0.52$ & $30.6 \pm 1.39$ & $31.78 \pm 8.64$ & $11.66 \pm 7.96$ \\
$3000 \mathrm{mg} / \mathrm{kg}$ & $23.9 \pm 1.41$ & $29.7 \pm 1.38$ & \\
\hline
\end{tabular}

to $50 \%$ ) with moderate activity (cell growth inhibition ranging from 50 to $70 \%$ ) and with large activity (cell growth inhibition ranging from 70 to $100 \%$ ). The average cell growth inhibition (IC\%) of cell treated with $50 \mu \mathrm{g} / \mathrm{mL}$ CDE is shown below (Table 4).

Table 3. Effect of Guettarda platypoda CDE, in different doses, on cell migration into peritoneal cavity on carrageenaninduced peritonitis in mice. Data are the mean $\pm \mathrm{SD}$ of at least six animals.

\begin{tabular}{lccc}
\hline \multicolumn{1}{c}{ Treated } & Dose $(\mathrm{mg} / \mathrm{kg})$ & $\begin{array}{c}\mathrm{N}^{\circ} \text { of } \mathrm{PMNL} / \mathrm{mL} \\
\left(\mathrm{x} 10^{6}\right)\end{array}$ & Inhibition (\%) \\
\hline Group 1 & 30 & $9.48 \pm 2.0$ & 6.7 \\
Group 2 & 50 & $3.35 \pm 0.7 *$ & 67.0 \\
Group 3 & 100 & $4.72 \pm 1.4 *$ & 53.5 \\
Group 4 & 150 & $3.40 \pm 0.7 *$ & 66.5 \\
Group 5 & 200 & $6.54 \pm 1.7 *$ & 35.6 \\
Indomethacin & 10 & $4.90 \pm 0.5 *$ & 51.8 \\
Control & - & $10.16 \pm 3.1$ & - \\
* $p<0.01 . \quad$ Significance was & determined with & ANOVA one-way \\
followed by Tukey's Test when compared with control group.
\end{tabular}

\section{Discussion}

The phytochemical analysis indicated the presence of significant secondary metabolites in the Guettarda platypoda DC., Rubiaceae, CDE. Some authors have reported the presence of several triterpene saponins, such as quinovic acid derivatives (Aquino et al., 1988a, 1989; Almeida, 1982; Bhattacharyya \& Almeida, 1985; Ferrari et al., 1986, Melo et al., 2008). In this study alkaloids were not identified but their presence was described in the ethanol extract by Almeida (1982) and detected the presence of $5 \alpha-$ carboxistrictosidina was detected by Ferrari et al. (1986) and Melo et al. (2008).

Results indicated that $G$. platypoda $\mathrm{CDE}$ has low oral acute toxicity. According to the criteria for acute toxicity by the GHS (Globally Harmonized Classification System) the fact that no serious injury or death occurred in any animal tested at the highest recommended dose $(2000 \mathrm{mg} / \mathrm{kg})$, indicate that the compounds were fit in class 5 (very low or no toxicity) (GHS, 2005). The absence of atypical behavior is also another indication of lack of toxicity of the compounds (Vital et al., 2009).

In order to evalute the effect of G. platypoda $\mathrm{CDE}$ on cell migration to the peritoneal cavity, we tested its effects on the induction of peritonitis by carrageenan. The statistical analysis revealed also that G. platypoda $\mathrm{CDE}$ evaluated, exhibited an inhibitory profile similar to indomethacin in the doses 50, 100, 150 and $200 \mathrm{mg} / \mathrm{kg}$. The potential anti-inflammatory activity by CDE may be due to synergistic action of quinovic acid glycosides already reported in the literature (Bhattacharyya \& Almeida, 1985; Aquino et al., 1988a, 1989, 1991; Ferrari et al., 1986) and the presence of beta-sitosterol (Bhattacharyya \& Almeida, 1985), flavonoids and the triterpnes identified in this study, since anti-inflammatory action of the metabolites mentioned above have been already described.

The action of $\beta$-sitosterol is similar to the hydrocortisone (Gupta, 1980) and the action of flavonoids was explained in part by its inhibitory effect on arachidonic acid metabolism (Silva et al., 2002).

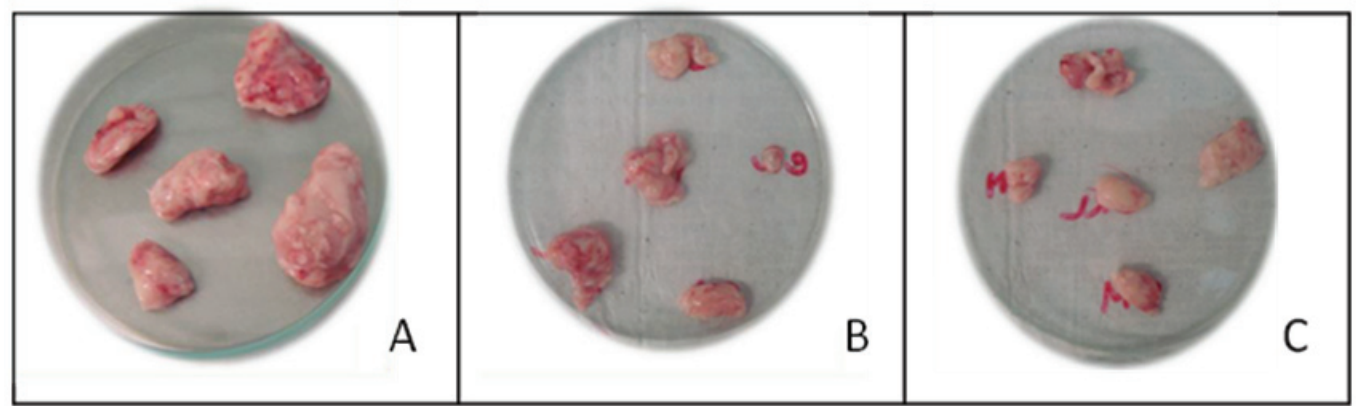

Figure 3. Illustration of antitumor evaluation sarcomatoses tumors. A. Control group; B. Group treated with CDE Guettarda platypoda dose $100 \mathrm{mg} / \mathrm{kg}$ (ST1); C. Group treated with CDE G. platypoda dose $200 \mathrm{mg} / \mathrm{kg}$ (ST2). 
Table 4. Percent inhibition of cell growth (IC\%) of the three tumor cell lines tested in a single dose $(50 \mu \mathrm{g} / \mathrm{mL})$ of Guettarda platypoda $\mathrm{CDE}$.

\begin{tabular}{lccc}
\hline \multicolumn{1}{c}{ Tumor lineage } & $\begin{array}{c}\text { Mean }(\mathrm{IC} \%) \\
\mathrm{CDE}(50 \mu \mathrm{g} / \mathrm{mL})\end{array}$ & $\begin{array}{c}\text { Mean }(\mathrm{IC} \%) \\
\text { Standard Deviation }(\mathrm{SD}) \mathrm{CDE}\end{array}$ & 0.6 \\
\hline HT29 & 15.2 & 0 & Noxorrubicina $(15 \mu \mathrm{g} / \mathrm{mL})$ \\
MCF-7 & 0 & 0.5 & 0.2 \\
NCI-H-292 & 1.7 & 0.2 \\
\hline
\end{tabular}

N.d: no determined.

Some flavonoids can block the biosynthetic processes of eicosanoids, which lead to an anti-inflammatory action, because it causes inhibition of COX-2 and nitric oxide synthase (Machado et al., 2008). It is also reported that triterpenes have anti-inflammatory activity, due to inhibition of nitric oxide and prostaglandin E2 synthesis (Moraes et al., 2012).

However, other disorders can lead to a decrease in PMNL migration. This probably happened with doses above $150 \mathrm{mg} / \mathrm{kg}$, observing an activity decrease anti-inflammatory, probably because exudate presented hemolysate due to the abundant presence of saponins in the roots of $G$. platypoda as described in this paper and by several other authors (Aquino et al., 1988a, 1989; Almeida, 1982; Bhattacharyya \& Almeida, 1985; Ferrari et al., 1986, Melo et al., 2008).

In the antitumor activity evaluation, the $G$. platypoda $\mathrm{CDE}$ is quite promising for the treatment of Sarcoma 180, but did not provide satisfactory results against the Ehrlich carcinoma. Therefore, it is important to emphasize the positive results of this study, which may improve our understanding in the use of this plant as an alternative anti-cancer therapy. For Sarcoma 180, as this strain is the most difficult to treat, according to Almeida et al. (2005), who emphasizes that sarcomatose tumors are more difficult to treat because they affect of bone and muscle regions. The identification of active principles and their mechanisms of action still need to be studied in order to enhance the promising effects in treatment of this strain. Probably flavonoids are responsible for the antitumor action due to its antioxidant capacity, and cell growth inhibitory activity in several tumor cell lines and induce apoptosis (Machado et al., 2008).

It was verified in this study that of G. platypoda CDE did not demonstrate cytotoxic activity. Analysis of cytotoxicity by MTT method has been used in the screening program of the National Cancer Institute of the USA (NCI), which tests more than 10000 samples each year (Skehan et al., 1990). It is a rapid, sensitive and inexpensive test. It was first described by Mosman (1983) as having the potential to analyze the viability and metabolic state of the cell. This is a colorimetric analysis based on conversion of 3-(4,5-dimethyl-2-thiazole)-2,5-diphenyl-2$\mathrm{H}$-tetrazolium bromide salt (MTT) into blue formazan due to mitochondrial enzymes present only in metabolically active cells. The study carried out employing cytotoxic the MTT method allows to define the cytotoxicity easily, but not the action mechanism (Berridge et al., 1996).

\section{Conclusions}

The methanolic extract of Guettarda platypoda DC., Rubiaceae has low toxicity and promising antiinflammatory activity at doses of 50,100 and $150 \mathrm{mg} /$ $\mathrm{kg}$ and antitumor activity to Sarcoma 180 at doses of $100 \mathrm{mg} / \mathrm{kg}$ and $200 \mathrm{mg} / \mathrm{kg}$. It's necessary to continue the studies with fractions to determine which fraction may will be more active. The cytotoxic activity did not indicate satisfactory results. These tests don't necessarily discard the potential of $\mathrm{CDE}$ against this activity and it is necessary additional tests using other cell strains and experimental models.

\section{Acknowledgment}

To CNPq for its financial support.

\section{References}

Agra MF, França PF, Barbosa-Filho JM 2007. Synopsis of the plants known as medicinal and poisonous in Northeast of Brazil. Rev Bras Farmacogn 17: 114-140.

Agra MF, Silva KN, Basílio IJLD, França PF, Barbosa-Filho JM 2008. Survey of medicinal plants used in the region Northeast of Brazil. Rev Bras Farmacogn 18: 472-508.

Almeida MZ 1982. Estudo fitoquímico e triagem farmacológica da casca da raiz da Guettarda platypoda DC. João Pessoa, p.133. Dissertação de Mestrado, Programa de Pós-graduação em Produtos Naturais, Universidade Federal da Paraíba.

Almeida VL, Leitão A, Reina LCB, Montanari CA, Donnici CL, Lopes MTP 2005. Câncer e agentes antineoplásicos ciclo-celular específicos e ciclocelular não específicos que interagem com o DNA: uma introdução. Quim Nova 28: 118-129.

Andersson L 1992. A provisional checklist of neotropical Rubiaceae. Scripta Botan Belg 1: 1-199.

Aquino R, Feo V, Simone F, Pizza C, Cirino G 1991. Plant 
Metabolites. New Compounds and Anti-Inflammatory Activity of Uncaria tomentosa. J Nat Prod 54: 453459.

Aquino R, Simone F, Pizza C, Cerri R, Mello JF 1988a. Quinovic acid glycosides from Guettarda platypoda. Phytochemistry 27: 2927-2930.

Aquino R, Simone F, Pizza C, Mello JF 1989. Further quinovic acid glycosides from Guettarda platypoda. Phytochemistry 28: 199-201.

Aquino R, Simone F, Senatore F, Pizza C 1988b. Iridoids and secoiridoids from Guettarda platypoda. Pharmacol Res Commun 20: 105-108.

Bahia 1979. Governo do Estado. Seplantec - Subsecretaria de Ciência e Tecnologia. Inventário de plantas medicinais do Estado da Bahia. Salvador.

Barbosa MRV, Souza EB, Jardim JG 2011. Rubiaceae. In: Checklist das Plantas do Nordeste (Versão 1.5). http:// www.cnip.org.br/bdpn/checklistNE.pdf, accessed Jan 2011.

Berridge MV, Tan AS, Mccoy KD, Wang R 1996. The Biochemical and Cellular Basis of Cell Proliferation Assays that Use Tetrazolium Salts. Biochem J 4: 1419.

Bertucci A, Haretche F, Olivaro C, Vázquez A 2008. Prospección química del bosque de galería del río Uruguay. Rev Bras Farmacogn 18: 21-25.

Bhattacharyya J, Almeida MZ 1985. Isolation of the constituents of the root-bark of Guettarda platypoda. J Nat Prod 48: 148-149.

Capasso A, Balderrama L, Silvila SC, Tommasi N, Sorretino L 1998. Phytochemical and pharmacological studies of Guettarda acreana. Planta Med 64: 348-352.

Costa AF 2001. Farmacognosia. $3^{\text {rd }}$ Ed., vol.3, Lisboa: Calouste Gulbenkian.

Cunha AP, Silva AP, Roque OR 2003. Plantas e produtos vegetais em fitoterapia. Lisboa: Calouste Gulbenkian, p. 21-61.

David JPL, David JM, Soares MBP, Costa JFO, Santos RR 2006. Introdução. In Lucchese AM (ed.). Instituto do Milênio do Semi-árido. Plantas da Caatinga: perfil botânico, fitoquímica e atividade biológica. vol.4. Recife: Associação de Plantas do Nordeste, p. 15-17.

Delprete PG 2004. Rubiaceae (Coffea or Quinine family). In Smith N, Mori SA, Henderson A, Stevenson DWm., Head SV (ed.) Flowering plants of the neotropics. Princeton: Princeton University Press, p. 328-333.

Ferrari F, Mesana I, Botta B, Mello JF 1986 Constituents of Guettarda platypoda. J Nat Prod 49: 1150-1151.

GHS 2005. A Guide to The Globally Harmonized System of Classification and Labeling of Chemicals (GHS). http://www.osha.gov/dsg/hazcom/ghsguideoct05.pdf, accessed Feb 2011.

Gupta MB, Nath R, Srivastava N, Shanker K, Kishor K, Bhargava KP 1980. Anti-inflammatory and antipyretic activities of $\beta$-sitosterol. Planta Med 39: 157-163.
Harbone JB 1998. Phytochemical Methods. $3^{\text {rd }}$ ed., London: Chapman \& Hall.

IGEduca 2010. Biodiversidade. http://www.igeduca.com.br/ artigos/acontece/biodiversidade.html, accessed Feb 2011.

Lima LF, Lima PB, Almeida-Jr EB, Zickel CS 2010. Morfologia de frutos, sementes e plântulas de Guettarda platypoda DC. (Rubiaceae). Biota Neotrop. 10: 155-160.

Machado H, Nagem TJ, Peters VM, Fonseca CS, Oliveira TT 2008. Flavonóides e seu potencial terapêutico. Bol Centro Biol Reprod 27: 33-39.

Matos FJA 1997. O formulário fitoterápico do professor Dias da Rocha. Fortaleza: UFC.

Melo SJ, Braz-Filho R, Lemos TLG, Santos HS, Fonseca AM, Xavier HS 2008. Derivados terpênico e indólico glicosilados das raízes de Guettarda platypoda D.C. (Rubiaceae). $31^{a}$ Reunião Anual da Sociedade Brasileira de Química. Águas de Lindóia, São Paulo.

Mól DFF 2010. Rubiaceae em um remanescente de floresta atlântica no Rio Grande do Norte, Brasil. Natal, 69 p. Dissertação de Mestrado, Programa de Pós-graduação em Ciências Biológicas, Universidade Federal do Rio Grande do Norte.

Moraes WF, Galdino PM, Nascimento MVM, Vanderlinde FA, Bara MTF, Costa EA, Paula JR 2012. Triterpenes involved in the anti-inflammatory effect of ethanolic extract of Pterodon emarginatus Vogel stem bark. $J$ Nat Med 66: 202-207.

Mossman T 1983. Rapid colorimetric assay for cellular growth and survival:application to proliferation and cytotoxicity assays. J Immunol Methods 65: 55-63.

Neu R 1956. A New reagent for differentiating and determining flavones of paper chromatograms. Naturwissenschaften 43: 82.

OECD (Organization for economicco-operation and development) 2001. Guideline for Testing of Chemicals: Acute Oral Toxicity-Acute Toxic Class Method. Guideline: 423. http://iccvam.niehs.nih.gov/SuppDocs/ FedDocs/OECD/OECD_GL423.pdf, acessed Jan 2012.

Pereira MS 2002. A família Rubiaceae na reserva biológica Guaribas, Paraíba, Brasil. Recife, 117 f. Dissertação de Mestrado, Programa de Pós-graduação em Biologia Vegetal, Universidade Federal de Pernambuco.

Pereira MS, Barbosa MRV 2004. A família Rubiaceae na Reserva Biológica Guaribas, Paraíba, Brasil. Subfamílias Antirheoideae, Cinchonoideae e Ixoroideae. Acta Bot Bras 18: 305-18.

Pessoa MCR 2009. Diversidade e riqueza da família Rubiaceae Juss. no Cariri paraibano. Recife, 83 f. Dissertação de Mestrado, Programa de Pós-graduação em Biologia Vegetal em Biologia Vegetal, Universidade Federal de Pernambuco.

Portal Brasil 2010. Por dentro do Brasil-Meio Ambiente. 34p. http://www.brasil.gov.br/cop/materiais-paradownload/por-dentro-do-brasil-2013-meio-ambiente- 
2013-setembro-2010, accessed Jan 2011.

Roberts EAH, Cartwright RA, Oldschool M 1957. Phenolic substances of manufactured tea. I. Fractionation and paper chromatography of water-soluble substances. $J$ Sci Food Agr 8: 72-80.

Russel JE 1982. Contribuition a l'estude botanique et chimiotaxonomique du genre Verbascum en Languedoc-Cevennes. França. Thèse de Doctorat, Université de Montpellier I.

Sharma OP, Dawra RK 1991. Thin-layer chromagraphye separations of lantadens, the pentacyclic triterpenoids from (Lantana camara) plant. J. Chromatogr 587: 351-354.

Skehan P, Storeng R, Scudiero D, Monks A, Mcmahon J, Vistica D, Warren JT, Bodesch H, Kenney S, Boyd MR 1990. New colorimetric cytotoxicity assay for anticancer-drug screening. J Natl Cancer I 82: 1107-1112.

Silva FRMB, Szpoganicz B, Pizzolatti MG, Willrich MAV, Sousa E 2002. Acute effect of Bauhinia forficata on serum glucose levels in normal and alloxan-induced diabetic rats. J Ethnopharmacol 83: 33-37.

Sugiura K, Stock CC, Sugiura MM 1955. The effect of phosphoramides on the growth of a variety of mouse and rats tumors. Cancer Res 2: 38-50.

Uchôa FT, Silva TG, Lima MC, Galdino SL, Pitta Ida R, Dalla Costa T 2009. Preclinical pharmacokinetic and pharmacodynamic evaluation of thiazolidinone PG15: an anti-inflammatory candidate. J Pharm Pharmacol 61: 339-345.

Vital FAC, Melo SJ, Silva TG, Carneiro S, Araújo JM, Mendonça-Jr FJB 2009. Avaliação da toxidade aguda e das atividades citotóxica, antimicrobiana e antiinflamatoria de 7-aril-2,3-diidrotiazolo[3,2- $\alpha$ ] pirimidin-5-ona-6-carbonitrila. Lat Am J Pharm 28: 507-512.

Wagner H, Bladt S 1996. Plant drugs analysis. A thin layer chromatography atlas. $2^{\text {nd }}$ ed., Munich: Springer.

\section{*Correspondence}

Sebastião J. Melo

Departamento de Antibióticos, Universidade Federal de Pernambuco

Av. Artur Sá s/n, Cidade Universitária, 50670-901 Recife-PE, Brasil

sebastiao.melo@ufpe.br

Tel/Fax: +558121268347 